\title{
Exploring environmental determinants of Fusarium wilt occurrence on banana in South Central Mindanao, Philippines
}

\author{
A.R. Salvacion ${ }^{1,7, *}$, T.C. Solpot ${ }^{2}$, C.J.R. Cumagun ${ }^{3}$, I.B. Pangga ${ }^{4}$, \\ D.B. Magcale-Macandog ${ }^{4}$, P.C.Sta. Cruz $^{5}$, R.B. Saludes ${ }^{6}$ and E.A. Aguilar ${ }^{5}$
}

Summary This study used Maximum Entropy (MaxEnt) to explore potential environmental determinants of Fusarium wilt occurrence on banana in south-central part of the Philippines. Different variables representing topographic, bioclimatic, and edaphic features of an area were tested against data of Fusarium wilt occurrence. Based on the results, precipitation during the driest month, precipitation during the wettest month, precipitation of the warmest quarter, slope, and elevation were the most important variables for predicting the probability of Fusarium wilt occurrence on banana. Results also suggest that among the variables tested, precipitation had the major contribution to the occurrence of Fusarium wilt.

Additional keywords: Climate, MaxEnt, Panama disease, topography

\section{Introduction}

Banana (Musa sp.) is an important subsistence food and high value commercial crop in the world (Ghag et al., 2015; Ravi and Vaganan, 2016). Banana is grown in more than 120 countries and its cultivation and related activities provide livelihood to many families in Africa, Asia, and Latin America (Roux et al., 2008; Ghag et al., 2015). In the Philippines, banana is the top fruit crop grown and a consistent dollar earner for the country (Solpot et al., 2016). In 2015, around 0.44 million hectares were planted with banana resulting in more than 9 million metric tons of produce with an estimated value

1 Department of Community and Environmental Resource Planning, College of Human Ecology

2 College of Agriculture, University of Southern Mindanao, Kabacan, North Cotabato, Philippines

${ }^{3}$ Institute of Weed Science, Entomology and Plant Pathology, College of Agriculture and Food Science

${ }^{4}$ Institute of Biological Sciences, College of Arts and Sciences

${ }^{5}$ Institute of Crop Science, College of Agriculture and Food Science

${ }^{6}$ Agrometeorology and Farm Structures Division, Institute of Agricultural Engineering, College of Engineering and Agro-Industrial Technology

7 School of Environmental Science and Management University of the Philippines Los Baños College 4031, Laguna, Philippines

* Corresponding author: arsalvacion@up.edu.ph of around USD 2.7 billion (PSA, 2017). Cavendish cultivars (50\%) have the largest contribution to the country's banana production followed by Cardava (28\%) and Lakatan (10\%) cultivars (Solpot et al., 2016). Top banana producing areas are mostly found in the southern part of the Philippines (Solpot et al., 2016).

Fusarium wilt, also known as Panama disease, is an important disease of banana that has devastated thousands of hectares of plantations worldwide (Ploetz, 2006, 2015a, 2015b; Ghag et al., 2015). Fusarium wilt is a soil-borne disease that causes wilt and severe die back to banana plant and can persist in the soil for at least 30 years (Stover, 1962; Cook et al., 2015). The disease is caused by the fungal pathogen Fusarium oxysporum f. sp. cubense (Foc) (Ploetz, 2006; 2015a; 2015b; Ghag et al., 2015). To enter the roots, Foc invades the epidermal cells on the root cap and elongation zone, and the small wounds along the lateral root base ( $\mathrm{Li}$ et al., 2011; Pattison et al., 2014). Then, Foc proceeds to the vascular system causing the disease (Li et al., 2011; Pattison et al., 2014). Once in the vascular tissues, the pathogen disrupts the water translocation causing wilting symptoms, such as drooping foliage and leaf chlorosis that start from the lower to the upper leaves, resulting in plant necro- 
sis and death (Li et al., 2011; Pattison et al., 2014; Ploetz, 2015a). In Australia alone, Cook et al. (2015) estimated an annual loss of more than 138 million USD to the banana industry due to Fusarium wilt.

Despite numerous studies and reviews on the epidemiology and management of Fusarium wilt of banana, there is limited literature on the environmental factors that affect its incidence and severity rates (Ploetz, 2006, 2015a, 2015b; Pattison et al., 2014; Ghag et al., 2015). For example, Pattison et al. (2014) found that Fusarium wilt expression is a function of water stress (deficit and excess) and heat unit requirement of banana. Deltour et al. (2017) showed that the higher the clay content, $\mathrm{pH}$, and electric conductivity in soil, the lesser severity of Fusarium wilt. Meanwhile, according to Perez-Vicente et al. (2014), severe infection is observed during the warmer and wet months of the year. Karangwa et al. (2016) reported that Fusarium wilt incidence and distribution is associated with elevation.

Maximum Entropy (MaxEnt) is a generalpurpose machine learning method that has a simple and precise mathematical formulation well suited for modeling the geographic distribution of species using presenceonly data (Phillips et al., 2006). According to Phillips et al. (2006), MaxEnt estimates a target probability distribution based on distribution of maximum entropy (i.e. closest to uniform), subject to a set of constraints related to incomplete information regarding the target distribution. For example, the pixels of a study area constitute the MaxEnt probability distribution while the pixels with occurrence records are the sampling points, and the different environmental variables or covariates (e.g. climate, elevation, soil, vegetation) represent the features (Phillips et al., 2006). MaxEnt also uses background points (points where presence or absence is unmeasured) that contrast against the occurrence points (presence locations) to estimate probability of occurrence (Merow et al., 2013). According to Phillips et al. (2006), MaxEnt has many advantages compared with other modeling methods. MaxEnt re- quires only presence data and environmental variables for the whole study area. Also, it can use both continuous and categorical data. In addition, it has efficient deterministic algorithms and performs better than other methods even with small sample size (Wisz et al., 2008). Detailed description of MaxEnt can be found in Phillips et al., (2006), Elith et al. (2011), Merow et al. (2013).

MaxEnt (Phillips et al., 2006) is the most popular software package used for modeling species geographic distribution using presence-only data (Elith et al., 2011; Merow et al., 2013). According to Elith et al. (2011), since MaxEnt became available in 2004, it has been extensively utilized for species distribution modeling that aims at finding correlates of species occurrence, mapping current and future species distribution across many ecological, evolutionary, conservation, and biosecurity applications. In fact, since 2006, there are thousands of publications about the application of MaxEnt (Merow et al., 2013). In plant pathology, several studies have used MaxEnt to identify environmental determinants and map potential distribution of plant diseases and their vectors (e.g. Wyckhuys et al., 2012; Bosso et al., 2016; Galdino et al., 2016; Narouei-Khandan et al., 2016; Shimwela et al., 2016; Vallejo Pérez et al., 2017). This study aims to identify environmental factors (i.e. topographic, edaphic, and bioclimatic) favoring Fusarium wilt infection of banana in South Central Mindanao, Philippines via the MaxEnt-modeling approach in order to develop a model for predicting disease occurrence and assessing the risk.

\section{Meterials and Methods}

\section{Presence-Only Data}

Presence-only data were adapted from the earlier study by Solpot et al. (2016) in which Foc-infected plant samples ( 75 points) were collected from different provinces in the south-central part of the country (Fig. 1). Plants that showed typical external and internal symptoms of Foc, such as wilting, yellowing of leaves, and pseudostem and corm 
discoloration were collected. Geographic coordinates of sampled plants were tagged using a global positioning system (GPS) receiver. Foc was isolated using the tissue plating technique. Full details of sampling and analysis of Foc sampled plants can be found in Solpot et al. (2016). Table 1 summarizes the number of Foc isolates by location and banana cultivar collected from the study area (Solpot et al., 2016).

\section{Environmental Data}

Environmental data used in the study included topographic, edaphic, and climatic variables (Table 2). Topographic data included elevation, slope, and aspect. Elevation data of the study area at $1 \mathrm{~km} \times 1 \mathrm{~km}$ spatial resolution was extracted from shuttle radar topography mission (SRTM) (Farr et al., 2007). Slope and aspect were derived from elevation data using terrain function of R software (Ihaka and Gentleman, 1996; $\mathrm{R}$ Core Team, 2014) raster package (Hijmans, 2014). Meanwhile, $1 \mathrm{~km} \times 1 \mathrm{~km}$ spatial resolution soil data (i.e. $\mathrm{pH}, \mathrm{CEC}$, organic carbon content, \% clay, \% silt, and \% sand) of the study area were downloaded from the SoilGrids database at $250 \mathrm{~m}$ resolution (Hengl et al., 2017). Bioclimatic data were derived from downscaled $(1 \mathrm{~km} \times 1 \mathrm{~km})$ Climate Research Unit Time Series (CRU TS) data (Harris et al., 2014) for the Philippines (Salvacion et al., 2018). Ten bioclimatic variables (Booth et al., 2014) were used in this study.

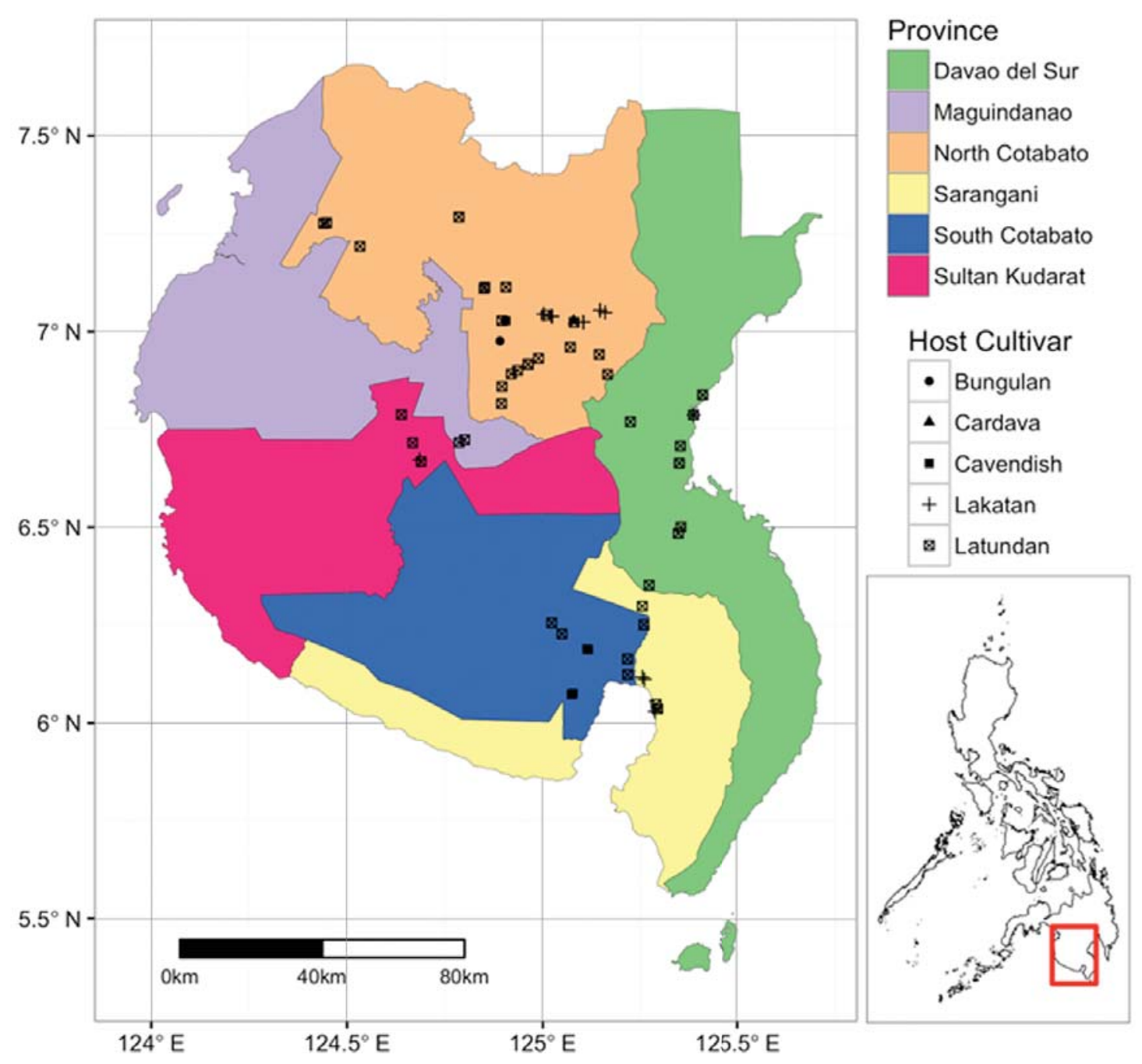

Figure 1. Location map of Fusarium oxysporum f. sp. cubense (Foc) and banana cultivars sampling points in south-central Mindanao, Philippines. 


\section{MaxEnt Modeling}

Presence-only data were split (80:20) into training (60 points) and test/validation data (15 points) sets. Also, background data (1000 points) were generated randomly across the study area. A step-wise mod- el building was also adapted by removing variables with permutation importance less than 5\% (Heumann et al., 2011; Kalle et al., 2013; Zeng et al., 2016). Permutation importance measures how the model depends on the variable (Galdino et al., 2016). In this

Table 1. Number of Fusarium oxysporum f. sp cubense (Foc) isolates per host cultivar collected in different provinces in south-central Philippines.

\begin{tabular}{|c|c|c|c|c|c|c|c|}
\hline \multirow[b]{2}{*}{ Host Cultivar } & \multicolumn{6}{|c|}{ Province } & \multirow[b]{2}{*}{ Total } \\
\hline & $\begin{array}{l}\text { North } \\
\text { Cotabato }\end{array}$ & $\begin{array}{l}\text { South } \\
\text { Cotabato }\end{array}$ & $\begin{array}{l}\bar{D} \\
\bar{D} \\
\text { D } \\
\bar{D} \\
\overline{0} \\
\tilde{D} \\
\sim\end{array}$ & $\begin{array}{l}\text { Davao } \\
\text { Del Sur }\end{array}$ & $\begin{array}{l}\text { Sultan } \\
\text { Kudarat }\end{array}$ & 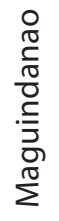 & \\
\hline Latundan (AAB) & 23 & 5 & 6 & 5 & 3 & 2 & 44 \\
\hline Lakatan (AAA) & 12 & 0 & 3 & 1 & 1 & 0 & 17 \\
\hline Cavendish (AAA) & 1 & 11 & 0 & 0 & 0 & 0 & 12 \\
\hline Cardaba (ABB) & 1 & 0 & 0 & 0 & 0 & 0 & 1 \\
\hline Bungulan (AAA) & 1 & 0 & 0 & 0 & 0 & 0 & 1 \\
\hline Total & 38 & 16 & 9 & 6 & 4 & 2 & 75 \\
\hline
\end{tabular}

Table 2. Environmental data for modeling Fusarium wilt in banana.

\begin{tabular}{|c|c|c|}
\hline Variable & Description & Unit \\
\hline \multicolumn{3}{|l|}{ Topographic } \\
\hline Elevation & Elevation & masl \\
\hline Slope & Slope & degrees \\
\hline Aspect & Aspect or slope direction & - \\
\hline \multicolumn{3}{|l|}{ Edaphic } \\
\hline Soil pH & Soil pH & $\mathrm{pH}$ units \\
\hline CEC & Cation Exchange Capacity & $\mathrm{cmolc} / \mathrm{kg}$ \\
\hline Organic carbon content & Organic carbon content & $\mathrm{g} / \mathrm{kg}$ \\
\hline \% Clay & Clay content (0-2 micro meter) mass fraction & $\%$ \\
\hline$\%$ Silt & Silt content (2-50 micro meter) mass fraction & $\%$ \\
\hline$\%$ Sand & Sand content (50-2000 micro meter) mass fraction & $\%$ \\
\hline \multicolumn{3}{|l|}{ Climatic } \\
\hline Bio 1 & Annual Mean Temperature & ${ }^{\circ} \mathrm{C}$ \\
\hline Bio 5 & Maximum Temperature of Warmest Month & ${ }^{\circ} \mathrm{C}$ \\
\hline Bio 6 & Minimum Temperature of Coldest Month & ${ }^{\circ} \mathrm{C}$ \\
\hline Bio 8 & Mean Temperature of Wettest Quarter & ${ }^{\circ} \mathrm{C}$ \\
\hline Bio 9 & Mean Temperature of Driest Quarter & ${ }^{\circ} \mathrm{C}$ \\
\hline Bio 12 & Annual Precipitation & $\mathrm{mm}$ \\
\hline Bio 13 & Precipitation of Wettest Month & $\mathrm{mm}$ \\
\hline Bio 14 & Precipitation of Driest Month & $\mathrm{mm}$ \\
\hline Bio 18 & Precipitation of Warmest Quarter & $\mathrm{mm}$ \\
\hline Bio 19 & Precipitation of Coldest Quarter & $\mathrm{mm}$ \\
\hline
\end{tabular}


study, MaxEnt package (Phillips et al., 2006; 2018) was run via R dismo package (Hijmans et al., 2016) using default settings.

\section{Model Validation}

Area under the curve (AUC) was calculated for both training and test data sets to determine the model's predictive power and potential over-fitting (Elith et al., 2011; Merow et al., 2013; Bosso et al., 2016). According to Rödder et al. (2009), AUC ranges from 0.5 (no predictive ability) to 1.0 (perfect prediction). An AUC value of 0.7-0.8 means that the model is useable, a value of 0.8-0.9 indicates good performance, and a value of 0.9-1.0 signifies very good predictive power (Rödder et al., 2009). Meanwhile, other measures (Table 3) of model's predictive accuracy were calculated using the test data points for model validation (Allouche et al., 2006). According to Allouche et al. (2006), true skill statistic (TSS) values range from -1 to +1 , where values of zero or less indicate poor performance and +1 indicates perfect agreement.

\section{Results}

\section{Step-wise model selection and valida- tion}

Only five out of the 19 variables in the initial model were left in the final model (Table 4). These variables included slope, elevation, precipitation on the driest month, precipitation on the wettest month, and precipitation on the warmest quarter. Precipitation during the wettest month had the highest permutation importance (26.1\%) followed by slope (24.9), while precipitation during the warmest quarter had the lowest (12\%). The AUC for the training and test data was 0.89 and 0.88 , respectively. This suggests that the final model performed very well with respect to the training and test data (Elith, 2000; Rödder et al., 2009; Abdullah et al., 2017). These results were further confirmed by the different measures of model accuracy (Allouche et al., 2006) in Table 5 using validation data points. Figure 2 shows the predicted presence of Fusarium wilt along with training (Fig. 2a) and validation data points (Fig. 2b).

Table 3. Measure of predictive accuracy of the model (Source: Allouche et. al, 2006).

\begin{tabular}{l|c|c}
\hline Measure & Formula & \multicolumn{1}{c}{ Description } \\
\hline Overall accuracy & $\frac{a+d}{n}$ & $\begin{array}{l}\text { Rate of correctly predicted } \\
\text { presence and absence data } \\
\text { Sensitivity }\end{array}$ \\
Specificity & $\frac{a}{a+c}$ & $\begin{array}{c}\text { Probability that the model } \\
\text { will correctly classify a pres- } \\
\text { ence data } \\
\text { Probability that the model } \\
\text { will correctly classify a ab- } \\
\text { sence data }\end{array}$ \\
Kappa & $\left.\frac{d}{b+d}\right)-\frac{(a+b)(a+c)+(c+d)(d+b)}{n^{2}}$ & $\begin{array}{c}\text { Kappa and TSS normalize } \\
\text { the overall accuracy by the } \\
\text { accuracy due chance alone }\end{array}$ \\
$\begin{array}{l}\text { True Skill Statistic } \\
\text { (TSS) }\end{array}$ & $\frac{(a+b)(a+c)+(c+d)(d+b)}{n^{2}}$ & \\
\hline
\end{tabular}

where: a-number of "presence" points for which was correctly predicted by the model

$b$ - number of "absence" points which the model predicted as "presence"

$c$ - number of "presence" points which the model predicted as "absent"

$\mathrm{d}$ - number of "absence" points for which was correctly predicted by the model

$\mathrm{n}-\mathrm{a}+\mathrm{b}+\mathrm{c}+\mathrm{d}$ 
Table 4. Permutation importance of environmental variables included in the final model.

\begin{tabular}{l|c}
\hline Variable & $\begin{array}{c}\text { Permutation } \\
\text { Importance } \\
(\%)\end{array}$ \\
\hline Climatic & 26.1 \\
Precipitation of Wettest Month & 21.2 \\
Precipitation of Driest Month & 12.0 \\
Precipitation of Warmest Quarter & \\
Topographic & \\
Slope & 24.9 \\
Elevation & 15.8 \\
\hline
\end{tabular}

\section{Environmental Responses}

In terms of bioclimatic variables, similar behavior was observed for the effect of precipitation during the driest (Fig. 3a) and wettest (Fig. 3b) months of the year. Higher probability was estimated for lower values of precipitation for these months (Fig. 4). For the wettest month of the year, the highest probability of occurrence (0.95) was calculated for monthly precipitation of $100 \mathrm{~mm}$ and eventually decreased to zero starting at monthly precipitation of $332 \mathrm{~mm}$ (Fig. 4a). For the driest month of the year, the highest probability of occurrence (0.46) was calculated at $43 \mathrm{~mm}$ of precipitation and decreased to zero starting at $120 \mathrm{~mm}$ monthly precipitation (Fig. 4b). On the other hand, the probability of Fusarium wilt occurrence showed a different response to precipitation during the warmest quarter (Fig. 4c). Higher probability of occurrence was observed on higher precipitation amount. More specifically, the highest probability (0.99) was estimated for quarterly precipitation of more than $839 \mathrm{~mm}$ and the lowest (0.01) for quarterly precipitation of less than $207 \mathrm{~mm}$ (Fig. 4c). Figure 5 shows the warmest quarter corresponding the sampling locations of Fusarium wilt occurrence.

Regarding topographic variables, higher probabilities of Fusarium wilt occurrence were estimated at lower slope and elevation values (Fig. 6). This means that higher chance of Fusarium wilt infection is expected in flat and lowland areas compared to
Table 5. Calculated measure of predictive accuracy of the final model.

\begin{tabular}{l|c}
\hline Measure & Value \\
\hline Overall accuracy & 0.70 \\
Sensitivity & 1 \\
Specificity & 0.68 \\
Kappa & 0.21 \\
True Skill Statistic (TSS) & 0.68 \\
\hline
\end{tabular}

sloping and upland ones. The highest probability of Fusarium wilt (0.47) was estimated at $0.10^{\circ}$ slope and decreased exponentially to zero starting at slope equal to $8.51^{\circ}$ (Fig. 6a). With respect to elevation, the highest probability of Fusarium wilt occurrence (0.23) was observed at 40 meters above sea level (masl) and exponentially decreased to zero starting at 1108 masl (Fig. 6b).

\section{Discussion}

Results suggest that bioclimate (i.e. precipitation) is the major contributory factor on Fusarium wilt occurrence. Low (less than $120 \mathrm{~mm}$ ) monthly precipitation during the driest and wettest month of the year also results to higher probability of occurrence. Conversely, higher probability of occurrence is expected for higher precipitation (greater than $800 \mathrm{~mm}$ ) during the warmest quarters. Topography (slope and elevation) of the area also influences occurrence of the disease. The probability of Fusarium wilt occurrence is higher on flat areas (less than $8^{\circ}$ of slope) and areas with low elevation (less than 40 masl).

The effect of precipitation and slope on the occurrence of Fusarium wilt of banana can be attributed to the response of Foc and banana plant to water availability or soil moisture. Low rainfall during the driest and wettest quarter can subject the banana plant to low moisture or water deficit stress condition making it highly susceptible to severe infection by the pathogen (Lee et al., 2004; Ghaemi et al., 2011; Pattison et al., 2014). Also, such conditions promote increased root colonization of tomato plants 

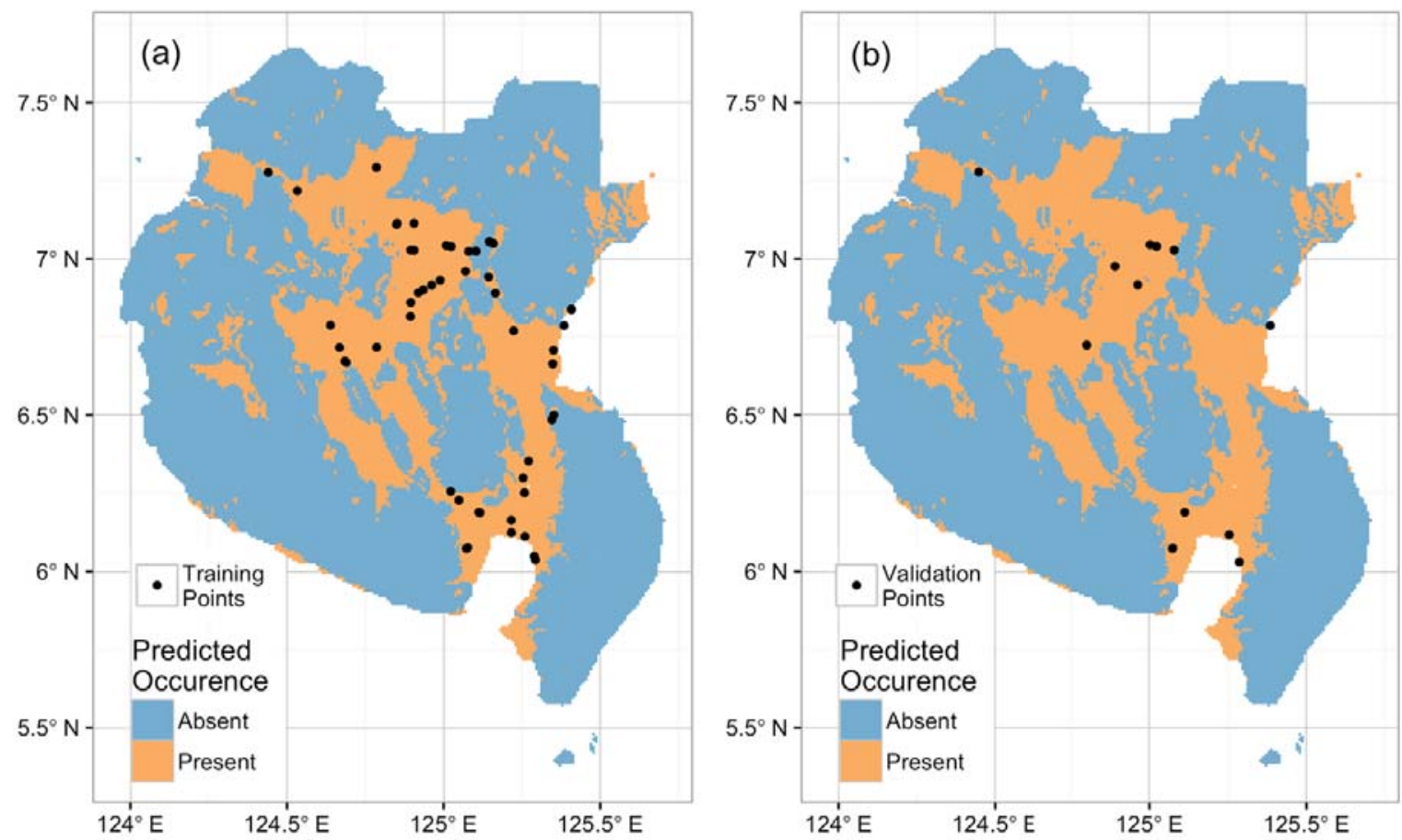

Figure 2. Predicted occurrence of Fusarium oxysporum f. sp. cubense (Foc) in south central Mindanao, Philippines, with (a) training, and (b) validation data points.
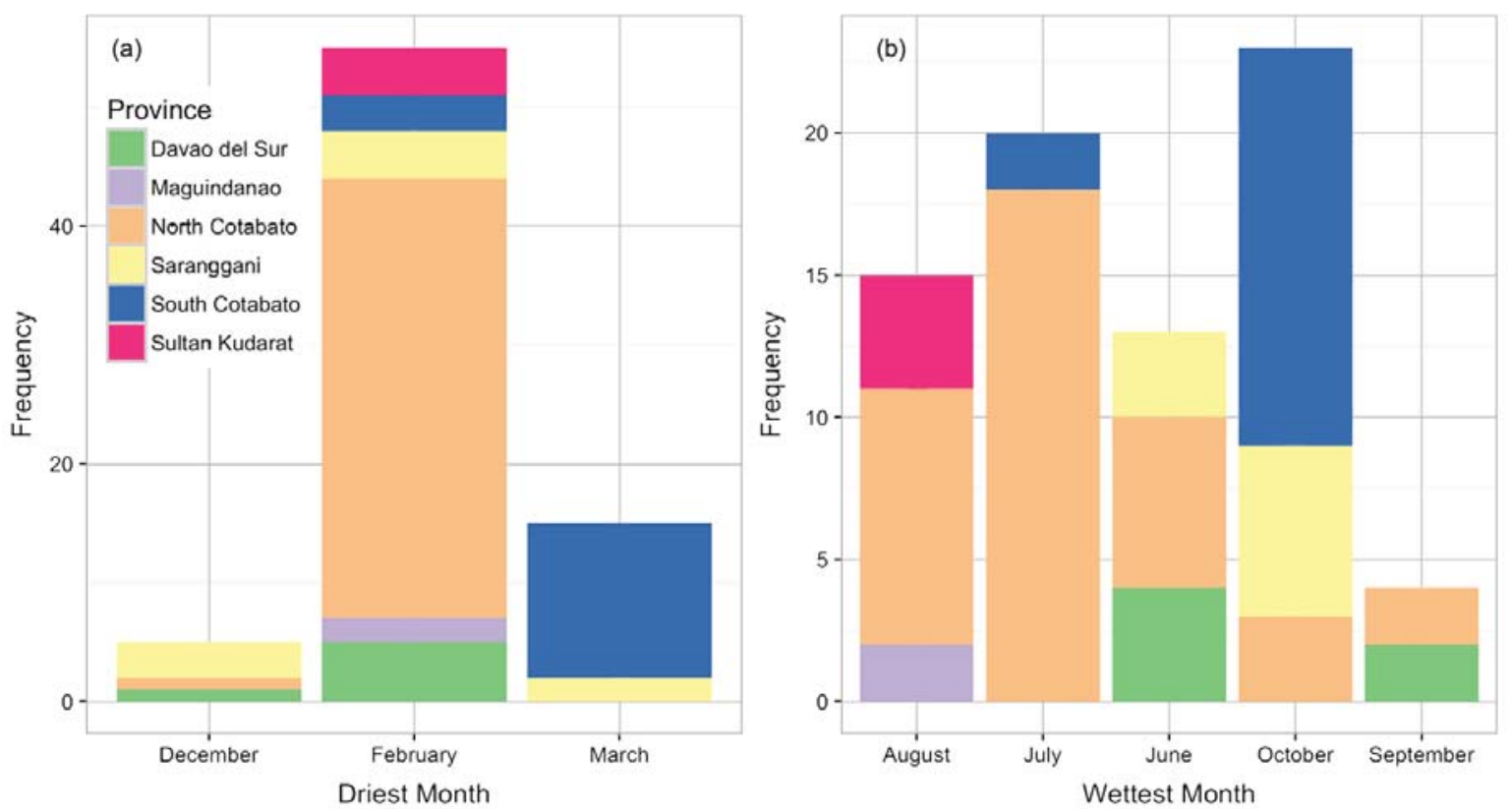

Figure 3. Driest (a) and wettest (b) months of each province in south-central Mindanao, Philippines, corresponding to Fusarium oxysporum f. sp. cubense (Foc) sampling points. 

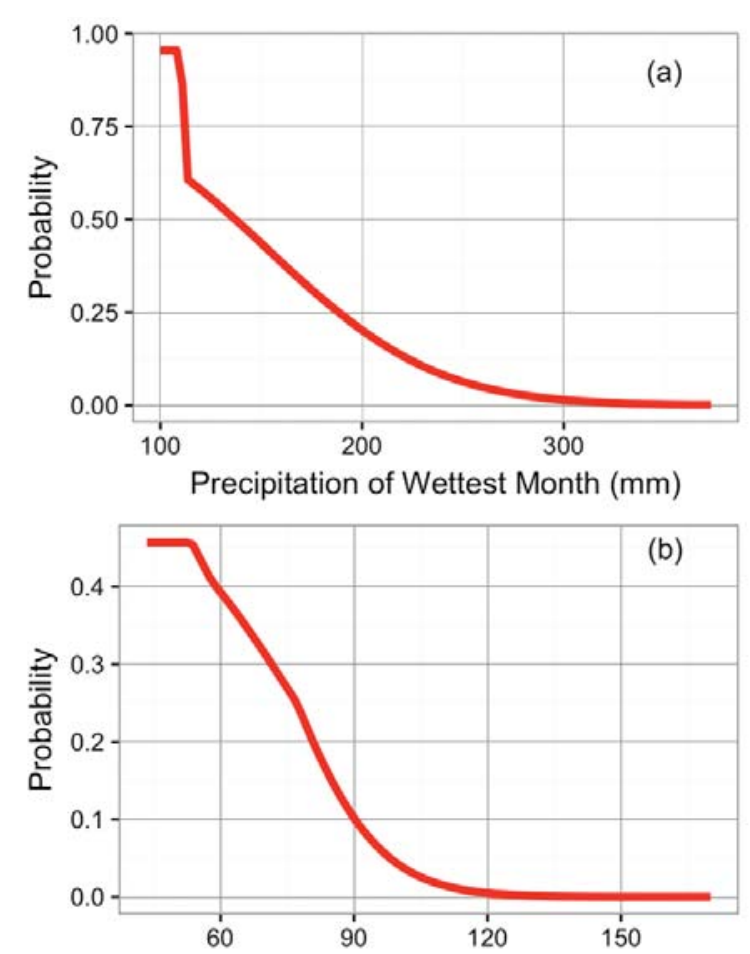

Precipitation of Driest Month ( $\mathrm{mm})$

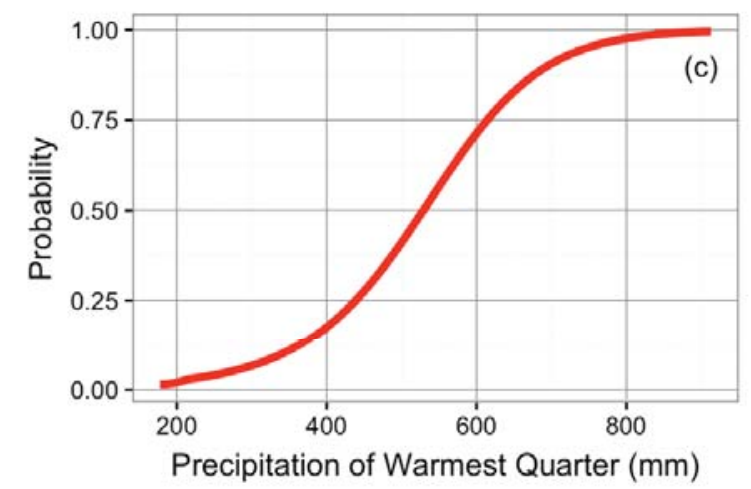

Figure 4. Response curve of Fusarium wilt (Fusarium oxysporum f. sp. cubense) occurrence with respect to precipitation on: (a) the wettest month; (b) the driest month, and (c) the warmest quarter in south-central Mindanao, Philippines.

by Fusarium oxysporum f. sp. lycopersici (Ghaemi et al., 2011). Meanwhile, higher precipitation during the warmest quarter can result in higher probability of Fusarium wilt occurrence because such conditions (warm and wet) are conducive to severe infection of banana by the pathogen (Perez-Vicente et al., 2014). Also, higher rainfall can saturate soil producing anoxic conditions, which can enhance Foc root infection (Aguilar, 1998; Aguilar et al., 2000; Pattison et al., 2014).

Areas with flat to near flat topography tend to have relatively higher moisture

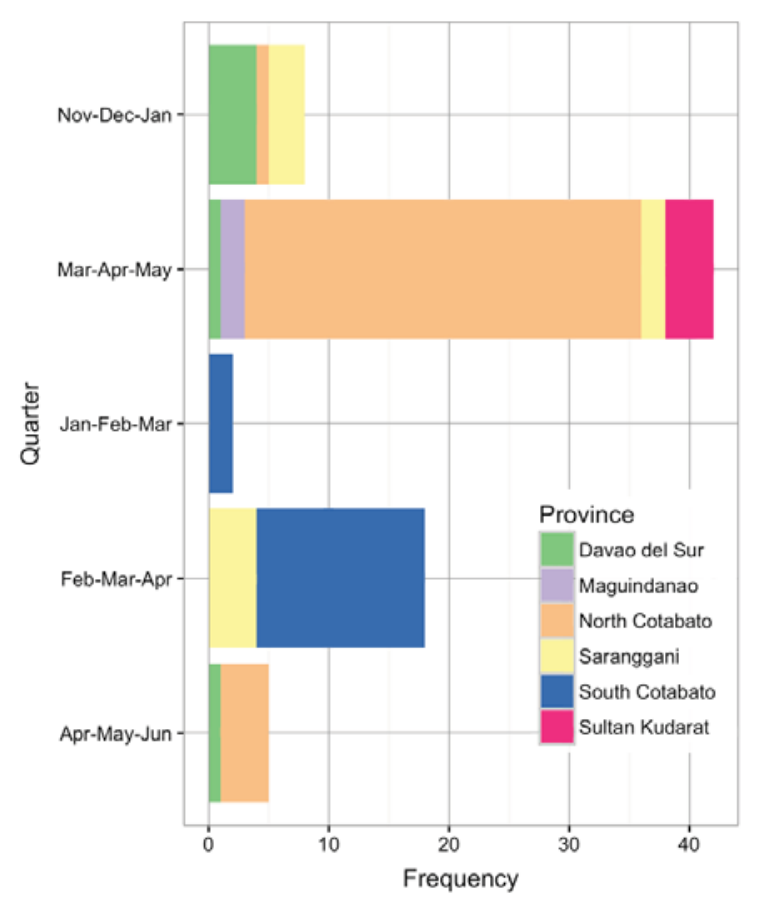

Figure 5. Warmest quarter of each province in south-central Mindanao, Philippines corresponding to Fusarium oxysporum f. sp. cubense (Foc) sampling points.

availability compared to the sloping ones, thus providing optimum conditions for fungal growth (Stover, 1953; Salvacion, 2016). In addition, slope can affect different soil properties (Su et al., 2010), which may also affect Foc presence or abundance (Fu et al., 2016; Deltour et al., 2017). This could probably be the reason why soil variables in this study showed no significant effect on Fusarium wilt occurrence.

The influence of elevation on Fusarium wilt incidence observed in the present study was similar to that of previous studies elsewhere (Kangire et al., 2001; Karangwa et al., 2016). According to Karangwa et al. (2016), the effect of elevation on Fusarium wilt development may be due to the temperature variation as influenced by elevation. Fusarium wilt development is encouraged by higher temperatures at lower altitudes (Karangwa et al., 2016).

The results of this study corroborate to previous studies conducted elsewhere. Lee et al. (2004) observed higher severity of Fusarium wilt in sweet potato at precipitation lower than $80 \mathrm{~mm}$ during planting 

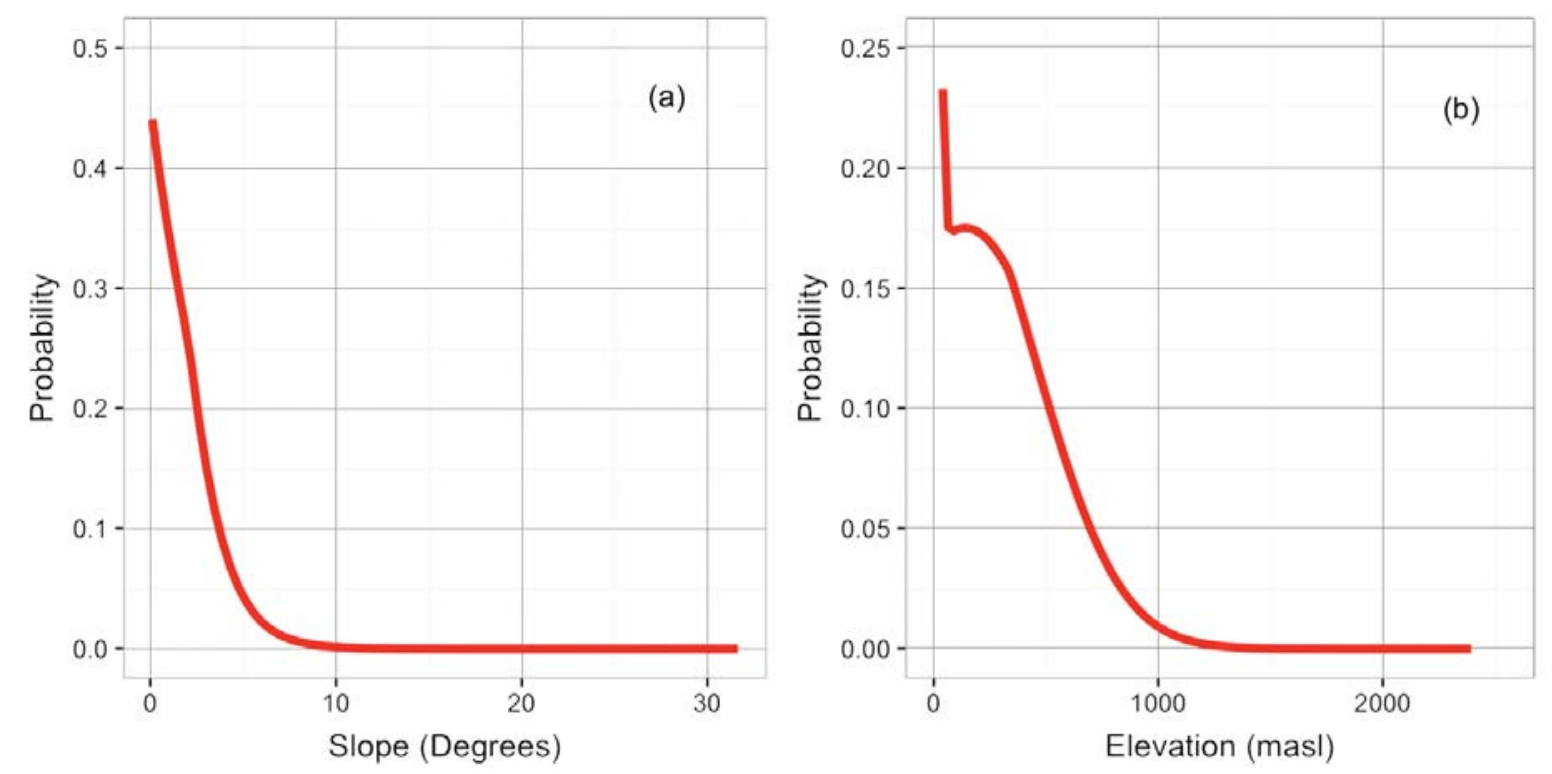

Figure 6. Response curve of Fusarium wilt (Fusarium oxysporum f. sp. cubense) occurrence with respect to: (a) slope, and (b) elevation (meters above sea level, masl) in south-central Mindanao, Philippines.

season. Fusarium wilt of sweet potato was higher in flat areas compared to that in areas situated in sloping sites (Lee et al., 2004). In Australia, Pattison et al. (2014) observed higher incidence of Fusarium wilt of banana during months with rainfall less than $100 \mathrm{~mm}$ and greater than $500 \mathrm{~mm}$. Karagwa et al. (2016) observed higher incidence of Fusarium wilt infection on banana farms located at elevations less than 1600 masl in east and central Africa.

Models like MaxEnt also have uncertainties resulting from sampling bias, quality of occurrence data, spatial resolution of environmental data, spatial autocorrelation and species characteristics (Dormann et al., 2008; Jarnevich et al., 2015; Galdino et al., 2016). In the case of the present study, sampling was done based only on the reported cases of Fusarium wilt occurrence. In addition, spatial autocorrelation among sampling points and environmental variables was not considered in the model building. Furthermore, the environmental data used in the study has also uncertainties (Hijmans et al., 2005; Hengl et al., 2017; Salvacion, Macandog et al., 2018). Lastly, the resolution of the environmental data might also have impact on the final model (Gillingham et al., 2012; West et al., 2015, 2016). At present, there is no or limited high resolution and updated environmental data (e.g. topography, climate, soil) in the country. Therefore, caution is recommended in interpreting the results of this study. Also, other approaches to analyze spatially referenced disease data might have different results (Turechek and McRoberts, 2013; Galdino et al., 2016).

The information, such as the range of environmental conditions favoring occurrence of Foc on banana and the model derived in this study can be used as a preliminary tool to assess potential risk of disease occurrence in other parts of the country. In addition, since climate has a major role in Fusarium wilt occurrence, the model derived from this study can also be used to determine potential impact of climate change on disease presence in the country. Such information can help farmers, managers, and policy makers to have an informed decision on how to avoid or minimize losses due to Fusarium wilt of banana.

The corresponding author would like to thank the Department of Science and Technology, Accelerated Science and Technology Human 
Resource Development Program-National Science Consortium-University of the Philippines Los Baños (DOST ASTHRDP-NSC-UPLB) for the financial support for his Doctoral study.

The authors have declared no conflict of interest.

\section{Literature Cited}

Abdullah, A.Y.M., Dewan, A., Shogib, M.R.I., Rahman, M.M. and Hossain, M.F. 2017. Environmental factors associated with the distribution of visceral leishmaniasis in endemic areas of Bangladesh: modeling the ecological niche. Tropical Medicine and Health, 45: 13. https://doi.org/10.1186/ s41182-017-0054-9.

Aguilar, E.A. 1998. Response of banana roots to oxygen deficiency and its implications for Fusarium wilt. In V. G. Saúco (Ed.), International Symposium on Banana in the Subtropics (Puerto de la Cruz, Tenerife, S ed., Vol. Acta Horticulturae No. 490, pp. 223-228). Leuven, Belgium: ISHS (Society for Horticultural Science).

Aguilar, E.A., Turner, D.W. and Sivasithamparam, K. 2000. Fusarium oxysporum f. sp. cubense inoculation and hypoxia alter peroxidase and phenylalanine ammonia lyase activities in nodal roots of banana cultivars (Musa sp.) differing in their susceptibility to Fusarium wilt. Australian Journal of Botany, 48: 589-596.

Allouche, O. Tsoar, A. and Kadmon, R. 2006. Assessing the accuracy of species distribution models: prevalence, kappa and the true skill statistic (TSS). Journal of Applied Ecology, 43: 1223-1232, https://doi.org/10.1111/j.1365-2664 .2006.01214.x.

Booth, T.H., Nix, H.A., Busby, J.R. and Hutchinson, M.F. 2014. Bioclim: the first species distribution modelling package, its early applications and relevance to most current MaxEnt studies. Diversity and Distributions, 20: 1-9, https://doi. org/10.1111/ddi.12144.

Bosso, L., Russo, D., Di Febbraro, M., Cristinzio, G. and Zoina, A. 2016. Potential distribution of Xylella fastidiosa in Italy: a maximum entropy model. Phytopathologia Mediterranea, [S.I.], v. 55, n. 1, p. 62-72. ISSN 1593-2095. Available at: $<$ http://www.fupress.net/index.php/pm/article/view/16429>.

Cook, D.C., Taylor, A.S., Meldrum, R.A. and Drenth, A. 2015. Potential economic impact of Panama disease (Tropical Race 4) on the Australian banana industry. Journal of Plant Diseases and Protection, 122: 229-237, https://doi.org/10.1007/ BF03356557.

Deltour, P., C. França, S., Liparini Pereira, O., Cardoso, I., De Neve, S., Debode, J. and Höfte, M. 2017. Disease suppressiveness to Fusarium wilt of ba- nana in an agroforestry system: Influence of soil characteristics and plant community. Agriculture, Ecosystems \& Environment, 239: 173-181, https://doi.org/10.1016/j.agee.2017.01.018.

Dormann, C.F., Purschke, O., Márquez, J.R.G., Lautenbach, S. and Schröder, B. 2008. Components of uncertainty in species distribution analysis: A case study of the Great Grey Shrike. Ecology, 89: 3371-3386, https://doi.org/10.1890/07-1772.1.

Elith, J. 2000. Quantitative Methods for Modeling Species Habitat: Comparative performance and an application to Australian plants. In Ferson, S. and Burgman, M. (Eds), Quantitative Methods for Conservation Biology, pp. 39-58. New York, NY: Springer New York, https://doi.org/10.1007/0387-22648-6_4.

Elith, J., Phillips, S.J., Hastie, T., Dudík, M., Chee, Y.E. and Yates, C.J. 2011. A statistical explanation of MaxEnt for ecologists. Diversity and Distributions, 17: 43-57, https://doi.org/10.1111/j.14724642.2010.00725.x.

Farr, T.G., Rosen, P.A., Caro, E., Crippen, R., Duren, R., Hensley, S., Kobrick, M., Paller, M., Rodriguez, E., Roth, L., Seal, D., Shaffer, S., Shimada, J., Umland, J., Werner, M., Oskin, M., Burbank, D. and Alsdorf, D. 2007. The Shuttle Radar Topography Mission. Reviews of Geophysics, 45, https://doi. org/10.1029/2005RG000183

Fu, L., Ruan, Y., Tao, C., Li, R. and Shen, Q. 2016. Continous application of bioorganic fertilizer induced resilient culturable bacteria community associated with banana Fusarium wilt suppression. Scientific Reports, 6: 27731. https://doi: 10.1038/srep27731.

Galdino, T.V. da S., Kumar, S., Oliveira, L.S.S., Alfenas, A.C., Neven, L.G., Al-Sadi, A.M. and Picanço, M.C. 2016. Mapping global potential risk of mango sudden decline disease caused by Ceratocystis fimbriata. PLOS ONE, 11: e0159450, https://doi. org/10.1371/journal.pone.0159450.

Ghaemi, A., Rahimi, A. and Banihashemi, Z. 2011. Effects of Water Stress and Fusarium oxysporum $\mathrm{f}$. sp. lycopersici on Growth (leaf area, plant height, shoot dry matter) and shoot nitrogen content of tomatoes under greenhouse conditions. Iran Agricultural Research, 29: 51-62, https://doi. org/10.22099/iar.2011.136.

Ghag, S.B., Shekhawat, U.K.S. and Ganapathi, T.R. 2015. Fusarium wilt of banana: biology, epidemiology and management. International Journal of Pest Management, 61: 250-263, https:// doi.org/10.1080/09670874.2015.1043972.

Gillingham, P.K., Huntley, B., Kunin, W.E. and Thomas, C.D. 2012. The effect of spatial resolution on projected responses to climate warming. Diversity and Distributions, 18: 990-1000, https://doi. org/10.1111/j.1472-4642.2012.00933.x.

Harris, I., Jones, P.D., Osborn, T.J. and Lister, D.H. 2014. Updated high-resolution grids of monthly climatic observations - the CRU TS3.10 Dataset. 
International Journal of Climatology, 34: 623642, https://doi.org/10.1002/joc.3711.

Hengl, T., Jesus, J.M. de, Heuvelink, G.B.M., Gonzalez, M.R., Kilibarda, M., Blagotić, A., Shangguan, W., Wright, M.N., Geng, X., Bauer-Marschallinger, B., Guevara, M.A., Vargas, R., MacMillan, R.A., Batjes, N.H., Leenaars, J.G.B., Ribeiro, E; Wheeler, I,; Mantel, S. and Kempen, B. 2017. SoilGrids250m: Global gridded soil information based on machine learning. PLOS ONE, 12: e0169748, https:// doi.org/10.1371/journal.pone.0169748.

Heumann, B.W., Walsh, S.J. and McDaniel, P.M. 2011. Assessing the application of a geographic presence-only model for land suitability mapping. Ecological Informatics, 6: 257-269, https://doi. org/10.1016/j.ecoinf.2011.04.004.

Hijmans, R.J. 2014. Raster: Geographic data analysis and modeling. R package version 2.3-12, http:// CRAN.R-project.org/package=raster..

Hijmans, R.J., Cameron, S.E., Parra, J.L., Jones, P.G. and Jarvis, A. 2005. Very high resolution interpolated climate surfaces for global land areas. International Journal of Climatology, 25: 19651978, https://doi.org/10.1002/joc.1276.

Hijmans, R.J., Phillips, S.J. and Elith, J. 2016. Dismo: Species Distribution Modeling. $\mathrm{R}$ package version 1.1-1, https://CRAN.R-project.org/ package $=$ dismo .

Ihaka, R. and Gentleman, R. 1996. R: A Language for Data Analysis and Graphics. Journal of Computational and Graphical Statistics, 5:299-314, https:// doi.org/10.1080/10618600.1996.10474713.

Jarnevich, C.S., Stohlgren, T.J., Kumar, S., Morisette, J.T. and Holcombe, T.R. 2015. Caveats for correlative species distribution modeling. Ecological Informatics, 29, Part 1: 6-15, https://doi. org/10.1016/j.ecoinf.2015.06.007.

Kalle, R., Ramesh, T., Qureshi, Q. and Sankar, K. 2013. Predicting the distribution pattern of small carnivores in response to environmental factors in the Western Ghats. PLOS ONE, 8: e79295, https:// doi.org/10.1371/journal.pone.0079295.

Kangire, A, Rutherfod, M.A. and Gold, C.S. 2001. Distribution of Fusarium wilt and the populations of Fusarium oxysporum f. sp. cubense on bananas in Uganda. In Molina, A.B.; Masdek, N.H. and Liew, K.W. (Eds), Banana Fusarium Wilt Management: towards Sustainable Cultivation, pp. 152161. Los Banos, Laguna: INIBAP-ASPNET.

Karangwa, P., Blomme, G., Beed, F., Niyongere, C. and Viljoen, A. 2016. The distribution and incidence of banana Fusarium wilt in subsistence farming systems in east and central Africa. Crop Protection, 84: 132-140, https://doi.org/10.1016/j. cropro.2016.03.003.

Lee, Y.H., Cha, K.H., Lee, D.G., Shim, H.K., Ko, S.J., Park, I.J. and Yang, K.Y. 2004. Cultural and rainfall factors involved in disease development of Fusarium wilt of sweet potato. Plant Pathology Journal, 20: 92-96.
Li, C., Chen, S., Zuo, C., Sun, Q., Ye, Q., Yi, G. and Huang, B. 2011. The use of GFP-transformed isolates to study infection of banana with Fusarium oxysporum f. sp. cubense race 4. European Journal of Plant Pathology, 131: 327-340, https:// doi.org/10.1007/s10658-011-9811-5.

Merow, C., Smith, M.J. and Silander, J.A. 2013. A practical guide to MaxEnt for modeling species' distributions: what it does, and why inputs and settings matter. Ecography, 36: 1058-1069, https:// doi.org/10.1111/j.1600-0587.2013.07872.x.

Narouei-Khandan, H.A., Halbert, S.E., Worner, S.P. and Bruggen, A.H.C. van. 2016. Global climate suitability of citrus huanglongbing and its vector, the Asian citrus psyllid, using two correlative species distribution modeling approaches, with emphasis on the USA. European Journal of Plant Pathology, 144: 655-670, https://doi. org/10.1007/s10658-015-0804-7.

Pattison, A.B., Wright, C.L., Kukulies, T.L. and Molina, A.B. 2014. Ground cover management alters development of Fusarium wilt symptoms in Ducasse bananas. Australasian Plant Pathology, 43: 465476, https://doi.org/10.1007/s13313-014-0296-5.

Perez-Vicente, L., Dita, M.A. and Martínez-de la Parte MSc, E. 2014. Technical manual prevention and diagnostic of Fusarium wilt (Panama disease) of banana caused by Fusarium oxysporum f. sp. cubense Tropical Race 4 (TR4), https://www.researchgate.net/profile/Einar_Martinez_de_la_Parte/ publication/273632807_Technical_Manual_Prevention_and_diagnostic_of_Fusarium_WiltPanama_Disease_of_banana_caused_by_Fusarium oxysporum_f_sp_cubense_Tropical_Race_4TR4/ links/ 55072e450cf27e990e050b7b/TechnicalManual-Prevention-and-diagnostic-of-Fusarium-WiltPanama-Disease-of-banana-caused-byFusarium-oxysporum-f-sp-cubense-TropicalRace-4TR4.pdf

Phillips, S.J., Anderson, R.P. and Schapire, R.E. 2006. Maximum entropy modeling of species geographic distributions. Ecological Modelling, 190: 231-259, https://doi.org/10.1016/j. ecolmodel.2005.03.026.

Phillips, S.J., Dudík, M. and Schapire, R.E. 2018. Maxent software for modeling species niches and distributions, url: http://biodiversityinformatics.amnh.org/open_source/maxent/

Ploetz, R.C. 2006. Fusarium Wilt of Banana Is Caused by Several Pathogens Referred to as Fusarium oxysporum f. sp. cubense. Phytopathology, 96: 653656, https://doi.org/10.1094/PHYTO-96-0653.

Ploetz, R.C. 2015a. Fusarium wilt of banana. Phytopathology, 105: 1512-1521, https://doi.org/10.1094/ PHYTO-04-15-0101-RVW.

Ploetz, R.C. 2015b. Management of Fusarium wilt of banana: A review with special reference to tropical race 4. Crop Protection, 73: 7-15, https://doi. org/10.1016/j.cropro.2015.01.007.

PSA. 2017. CountrySTAT Philippines. Other Crops; 
Area Planted or Harvested. http://countrystat. psa.gov.ph/ (accessed 13 May 2017)

R Core Team. 2014. R: A Language and Environment for Statistical ComputingR Foundation for Statistical Computing, 2014, http://www.R-project. org/.

Ravi, I. and Vaganan, M.M. 2016. Abiotic stress tolerance in banana. In Rao, N.K.S.; Shivashankara, K.S. and Laxman, R.H. (Eds), Abiotic Stress Physiology of Horticultural Crops, pp. 207-222. Springer India, https://doi.org/10.1007/978-81-3222725-0_12

Rödder, D., Schmidtlein, S., Veith, M. and Lötters, S. 2009. Alien invasive slider turtle in unpredicted habitat: A matter of niche shift or of predictors Studied? PLOS ONE 4: e7843, https://doi. org/10.1371/journal.pone.0007843.

Roux, N., Baurens, F.-C.; Doležel, J.; Hřibová, E.; Heslop-Harrison, P., Town, C., Sasaki, T., Matsumoto, T., Aert, R., Remy, S., Souza, M. and Lagoda, P. 2008. Genomics of banana and plantain (Musa spp.). Major Staple Crops in the Tropics 83111, https://doi.org/10.1007/978-0-387-71219$2 \_4$.

Salvacion, A.R. 2016. Terrain characterization of small island using publicly available data and open- source software: a case study of Marinduque, Philippines. Modeling Earth Systems and Environment, 2: 1-9, https://doi.org/10.1007/ s40808-016-0085-y.

Salvacion, A.R, Magcale-Macandog, D.B., Cruz, P.C.S., Saludes, R.B., Pangga, I.B. and Cumagun, C.J.R. 2018. Evaluation and spatial downscaling of CRU TS precipitation data in the Philippines. Modeling Earth Systems and Environment 4: 891-898, https://doi.org/10.1007/s40808-018 $-0477-2$.

Shimwela, M.M., Blackburn, J.K., Jones, J.B., Nkuba, J., Narouei-Khandan, H.A., Ploetz, R.C., Beed, F. and Bruggen, A.H.C. 2016. Local and regional spread of banana Xanthomonas wilt (BXW) in space and time in Kagera, Tanzania. Plant Pathology, 66(6): 1003-1014. https://doi.org/10.1111/ ppa.12637

Solpot, T.C., Pangga, I.B., Baconguis, R.D.T. and Cumagun, C.J.R. 2016. Occurrence of Fusarium oxysporum f. sp. cubense Tropical race 4 and other genotypes in banana in South-Central Mindanao, Philippines. Philippine Agricultural Scientist, 99: 370-378.

Stover, R.H. 1953. The effect of soil moisture on Fusarium species. Canadian Journal of Botany, 31: 693-697. https://doi.org/10.1139/b53-050.
Stover, R.H. 1962. Fusarial wilt (panama disease) of bananas and other Musa species. Commonwealth Mycological Institute.

Su, Z.-A., Zhang, J.-H. and Nie, X.-J. 2010. Effect of soil erosion on soil properties and crop yields on slopes in the Sichuan Basin, China. Pedosphere, 20: 736-746. https://doi.org/10.1016/S10020160(10)60064-1.

Turechek, W.W. and McRoberts, N. 2013. Considerations of scale in the analysis of spatial pattern of plant disease epidemics. Annual Review of Phytopathology, 51: 453-472. https://doi. org/10.1146/annurev-phyto-081211-173017.

Vallejo Pérez, M.R., Téliz Ortiz, D., De La Torre Almaraz, R, López Martinez, J.O. and Nieto Ángel, D. 2017. Avocado sunblotch viroid: Pest risk and potential impact in México. Crop Protection, 99: 118-127. https://doi.org/10.1016/j. cropro.2017.05.015.

West, A.M., Kumar, S., Brown, C.S., Stohlgren, T.J. and Bromberg, J. 2016. Field validation of an invasive species Maxent model. Ecological Informatics, 36: 126-134, https://doi.org/10.1016/j. ecoinf.2016.11.001.

West, A.M., Kumar, S., Wakie, T., Brown, C.S., Stohlgren, T.J., Laituri, M. and Bromberg, J. 2015. Using high-resolution future climate scenarios to forecast Bromus tectorum invasion in rocky mountain National Park. PLOS ONE, 10: e0117893, https://doi.org/10.1371/journal.pone.0117893.

Wisz, M.S., Hijmans, R.J., Li, J., Peterson, A.T., Graham, C.H. and Guisan, A. 2008. Effects of sample size on the performance of species distribution models. Diversity and Distributions, 14: 763-773. https://doi.org/10.1111/j.1472-4642 .2008.00482.x.

Wyckhuys, K.A.G., Korytkowski, C., Martinez, J., Herrera, B., Rojas, M. and Ocampo, J. 2012. Species composition and seasonal occurrence of Diptera associated with passionfruit crops in Colombia. Crop Protection, 32: 90-98. https://doi. org/10.1016/j.cropro.2011.10.003.

Zeng, Y., Low, B.W. and Yeo, D.C.J. 2016. Novel methods to select environmental variables in MaxEnt: A case study using invasive crayfish. Ecological Modelling, 341: 5-13. https://doi.org/10.1016/j. ecolmodel.2016.09.019.

Received: 11 April 2018; Accepted: 2 March 2019 


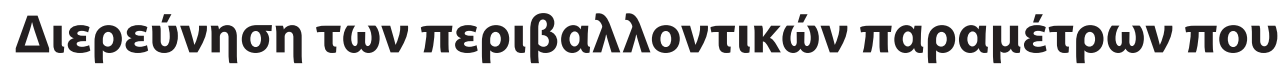

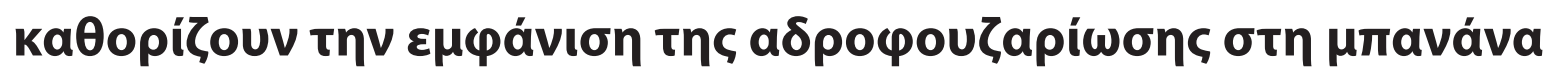

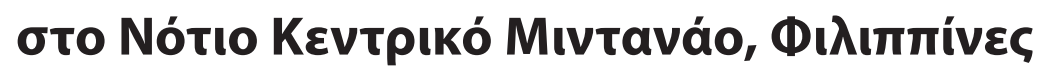

\author{
A.R. Salvacion, T.C. Solpot, C.J.R. Cumagun, I.B. Pangga, \\ D.B. Magcale-Macandog, P.C.Sta. Cruz, R.B. Saludes Kaı E.A. Aguilar
}

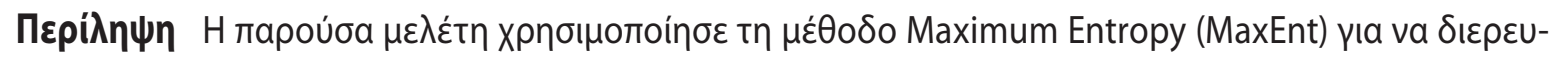

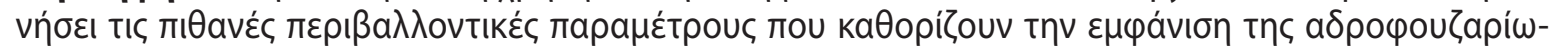

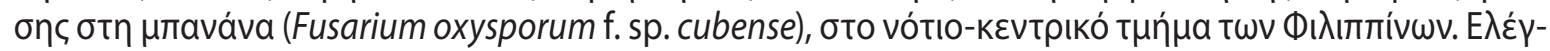

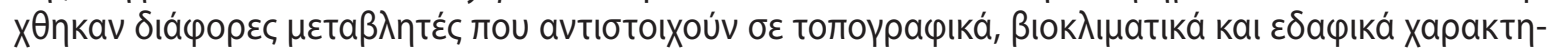

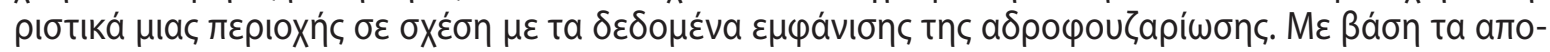

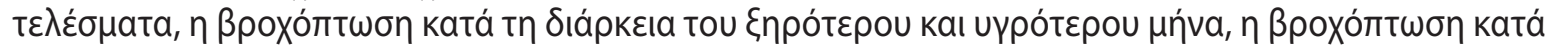

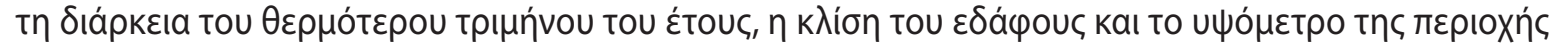

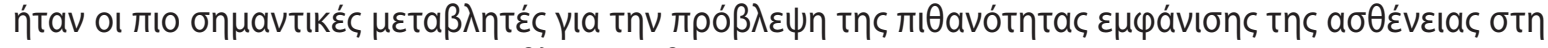

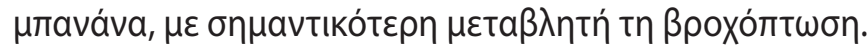

Hellenic Plant Protection Journal 12: 78-90, 2019 